\title{
Dancing through Post-Youth Cultures
}

\author{
TARA BRABAZON \\ CHARLES STURT UNIVERSITY
}

Ros Jennings and Abigail Gardner (eds)

'Rock On': Women, Ageing and Popular Music

Ashgate, Farnham, 2012

ISBN 9781409428411

RRP $£ 55.00$

Andy Bennett and Paul Hodkinson (eds)

Ageing and Youth Cultures: Music, Style and Identity

Berg, London, 2012

ISBN 9781847888358 (pb), $9781847888365(\mathrm{hb})$

RRP \$34.99 (pb), \$110.00 (hb)

'I smell youth, vintage youth.'

Neil Tennant, It Couldn't Happen Here (1987)

I have a rave hat. I bought it in 1989. Part collapsed top hat, part bedazzled cowboy Stetson, it captures a moment where I thought I had the swagger of the Stone Roses, the cheekiness of The Shaman and the ice and fire passion of Heather Small. Yes, I 
was delusional. But I was dancing through my delusion. The years between 1988 and 1994 mapped the person I could become: aspirational, post-fashion, postfeminist, presentist, ironic, self-effacing, inclusive and always moving. Our dancing selves are our best selves. When the dancing stops, a bit of us-the laughing, dreaming, jumping part-dies.

But perhaps not. That hat has remained with me through twenty years, four countries and eight universities. I wear it in public very rarely, but I put it on once a week. It is a tactile, textile memory of the self I wanted to become, and the journey I still have to travel. I wear my hat and the (post)youth culture it signifies with both humour and history. I am like a techno-version of Miss Haversham. My fashion clock stopped in 1995 and my mobile corporeal museum (in other words, my body) continues to circulate, much to the confusion of both small children and colleagues. In many ways I remain cocooned in that moment of possibility, connectivity and dancing even as the realities of the present shatter these memories.

The most amazing coincidence of working in cultural studies during that time of exploding popular culture and post-youth culture was that we-as young researchers-shared this time with older dancing scholars who catalogued our lives and theorised our experiences. The Manchester Institute for Popular Culture (MIPC) at Manchester Metropolitan University seemed the coolest place in the world. Reading and writing from Perth in Western Australia, I felt like my nose was pressed against the window pane of the Hacienda, with 24-hour party people strutting to A Guy Called Gerald's 'Voodoo Ray'. I even applied to complete my PhD at the MIPC. It was only then that 'life'-adulthood-got in the way. I had to choose between reality - a rare chance for a full-time academic post in New Zealand-or living the dream by completing a full-time doctoral program at the MIPC. I went to Wellington to take up a lectureship. But, like the best post-youth culture stories, the dream did not end as I moved through the turnpike of academic responsibilities. Just over five years later, I met Steve Redhead, the director of the MIPC and the pivotal scholar of youth, music, sport, dancing, acid house and rave. For my generation of cultural studies scholars, this man was our Wizard of Oz. He wrote the theory as we were dancing it. In 2001, I was charged with meeting him off a flight at Perth airport and introducing his keynote address for the Australian and New Zealand Communication 
Association (ANZCA). Finally, I was meeting the man who could have been my supervisor if 'adult' life had not got in the way. We were married within six months.

My rave hat-and my marriage-confirms that personal and collective histories of youth are rarely linear. They do not clean up after themselves. Redundancies, obsolescence and inappropriate malapropisms arch from the normative narratives of education, work, relationships and family. Youth-like all identity formations-requires a story to enable meaning. Without the tale, my hat is just a hat. However, the resultant narrative is not simple, chronological or positivist. It loops, cycles and bounces.

Two new books enter this culture and explore time, space, bodies, music and post-youth culture. They prise open the productive and overlapping terrain between cultural studies, media studies and ageing studies. 'Rock On': Women, Ageing and Popular Music, edited by Ros Jennings and Abigail Gardner as part of Ashgate's Popular and Folk Music Series, and Ageing and Youth Cultures: Music, Style and Identity, edited by Andy Bennett and Paul Hodkinson for Berg, in both their strengths and weaknesses capture much of what has happened to (anti-post-interdisciplinary) cultural studies during the last decade. As edited collections they lack the overarching development of a theory or argument, but both feature fascinating chapters that justify the price of admission.

Rock On comprises two parts in eight chapters. Part One musters essays on 'Renewal, recycling and renegotiation', while Part Two summons a shard of Kenneth Wolstenholme's maxim 'It's not over ...' The introduction by the editors is strong, asking 'What might be the relationship between Madonna's hands, Courtney Love's face and Grace Jones' "hindquarters"? The answer', it turns out, 'is that these three body parts are fetishized for how they might illustrate, deny or obscure aging'. (1) Old popular culture activates a complex intellectual space for scholars. The confronting nature of being 'ageing academics and popular music fans' (1) makes personal textual and social meanings. This book particularly focuses on women and ageing, an important corrective to the research literature that nonetheless excludes the recent appearance of Mick Jagger and Keith Richards at Glastonbury, a gig described by the Daily Mail as 'The night of the living dead'. At a certain point-even for men-the heroic label of vintage or classic or 'good for their age' is replaced by a karaoke circus of wrinkles, lumps, bumps and lines. It took the Stones until well into 
their seventies to become their own retirement village tribute act. Sexism is not as kind to women.

Something weird happened to femininity through the 2000s. Whalebone corsets have been replaced with corsets of muscle. Botox, fillers, liposuction and gastric bands have been normalised. Women's faces have been ironed of emotion. Bodies have been pummelled and pinched into a diversity of shapes and sizes. There have been scars. Madonna's hands-now represented by the compound search term 'Madonna hands' - show the cost of attempting to Dorian Gray a body without the convenience of a portrait in the attic. Stevie Nicks and Debbie Harry-effervescently beautiful women-have a category in Google Images bitingly labelled 'fat photos' which brutally chart their ageing and associated fluctuations in weight. Much less attention is placed on Paul McCartney's hair and its changing colourway from brown to grey and back to a deep brown just in time for his remarriage.

Madonna is important to this collection, perhaps too important. Giving two out of eight chapters to Madonna is excessive since it dates the research and offers a particular arc about ageing and popular music that obscures other models and modes. Lucy O’Brien's 'Madonna: Like a Crone' represents the icon through the gauze of maiden, mother and crone. O'Brien mentions in only one sentence the ageing of female performers distinctive to folk. Joan Baez, Joni Mitchell and Emmylou Harris do not have 'Madonna hands', but they do have a crucial stature in popular music. While selections of topics must always be made in edited collections, there is something askew in a book on ageing and music in which Madonna receives two chapters and Mitchell is not even included in the index. The standout chapters are Abigail Gardner's 'Framing Grace: Shock and Awe at the Ageless Black Body' and Paula Hearsum's '27 Forever: Kristen Pfaff and the Coverage of Death as the Representation of a Gendered Musical Life'. The latter piece on Hole's bass player not only activates studies of decline, suicide and death, but also remembers the history of female musicians rather than singers. Complexity is also present in Catherine Strong's contribution on Hole, “I'd stage-dive, but I'm far too elderly": Courtney Love and Expectations of Femininity and Ageing'.

My critique of the book reflects my wider concern with a strand of media and cultural studies scholarship that I blame for much of the institutional decline in our fields. Jennings and Gardner describe the 'representational difficulty' of ageing. (6) 
There are two reasons to express concern about such a statement. First, it remains an awkward notion that representation can ever operate in a seamless or untroubled way: it is not possible to unhook the floating signifiers of ageing and reconnect them with deept narratives of meaning, identity and justice. Second-and parking postmodernism for a moment-the way semiotics or, more precisely, textual analysis has been reified has meant that 'reading' has replaced 'thinking'. It is almost as if writers are trapped in a Ground Hog Day of first-year semiotics lectures where representation has become an empirical 'real' to be revealed by eagle-eyed scholars summoning Barthes, Saussure or, more realistically, an undergraduate textbook with a title like Introduction to Cultural Studies or Cultural Studies for Dummies. Ageing has many challenges but the most significant one is not representation. That is the problem with this book: the textual analysis of television programs and concerts has replaced more theoretically and politically complex scholarship. In its approach this book could have been written in 1982 rather than 2012. Even the content makes it seem a dated collection from which digitisation is noticeably absent. This gap is problematic in terms of how the web recycles and repositions 'old' and 'new', 'young' and 'old'. The researchers have failed to grasp the impact of the downloading economy that punctuates contemporary popular music. Digitisation is a denial of death. In the discourse of downloads, Abba songs mix with Christine Perfect. Sandy Denny is next to Janice Joplin on the playlist. Grace Jones and Gaga are equal before the download.

To return to men and Glastonbury 2013 for a moment, consider the performer who filled the Legends slot: Kenny Rogers. The Glastonbury audience's response to 'The Gambler' was beyond camp or nostalgia; thousands of people filtered their life through the bizarre lyrics of that song as if they were a drunken Greek chorus. Through much of our institutional history, cultural studies scholars have been desperately seeking the audience, as Ien Ang memorably put it in 1991 . We have categorised encoding and decoding, resistive readers and prosumers, yet can still forget that particular cultural artefacts travel in odd ways. They loop and hook into the deep time of listeners, embedding themselves into the narrative of people's lives. While digitisation cuts bodies away from bits, bodies matter in any discussion of men, women, ageing and popular culture. They are important to 'Rock On'. While there is too much focus on representation, rather than social structures or politics, 
and too much textual analysis, there are some fascinating chapters that will be the basis of further studies. But in edited collections, what is absent is often more important than what is present. This is a short book and the fragmentation and repetition is made worse because there is no conclusion. It simply ends with another chapter on Madonna.

Bodies also matter in Andy Bennett and Paul Hodkinson's Ageing and Youth Cultures, which is structured in four sections: 'Ageing, Image and Identity', 'Constraints of the Ageing Body', 'Resources and Responsibilities', and 'Ageing Communities'. The last two sections are much stronger than the first two. In the first half of the book it is almost as if Angela McRobbie and Dick Hebdige have exited the TARDIS from 1980 and are now working in adjacent offices. Yet so much has happened to subcultural theory and ethnographic methods, particularly through the advent of digitisation. Sarah Pink's research is one exemplary strand of scholarship that has simply been cut away from the reading list of the researchers in this monograph. Nonetheless, I would advise readers to stay with the book: chapters eight to twelve are excellent and could be deployed in a range of projects on popular music, popular memory, (post)youth culture and, provocatively, tourism studies.

Most of Aging and Youth Cultures moves beyond textual analysis and sweeps to the other end of the cultural studies continuum, ethnography and participant observation. The editors rehearse the diverse and complex histories encircling the word 'youth'. This complexity is increased when investigating the relationship between youth culture and popular music. Since Little Richard pounded the keys to 'Tutti Frutti', it has been assumed that young people are the 'natural' audience for pop. Such an assumption was incorrect in the 1950s. It is incorrect now. Popularmusic performers have always been troubled by ageing. This is not new. From Bruce Springsteen 'sitting around getting older' while 'Dancing in the Dark' to The Who's hoping for death before 'getting old' in 'Won't get Fooled Again', the binary of 'old' and 'young' has always been contextually and politically muddied in popular culture. Ageing and Youth Cultures explores what happens to music as we age. Yes, there is the unwelcome return of 'spectacular youth subcultures', albeit with a few more wrinkles, crinkles and crinklies. But participant observation has also returned, along with subject interviews. 
Yet, in terms of both method and theory, this book remains disappointing. There is solid data gathered through conventional methods but, as with the Jennings and Gardner book, the same studies could have been written three decades ago. Particularly in the first half of the book, there is little evidence of the deep critical thinking about the revisions to cultural studies paradigms that have occurred in that time. For example, Ross Haenfler's study of ageing straight edgers, 'More than the Xs on My Hands', states in conclusion: 'Overemphasizing the style component of music subcultures may inadvertently exclude the study of older adherents for whom style is no longer central to their subcultural self'. (23) Hopefully we have moved beyond Dick Hebdige's Subculture: The Meaning of Style, which was nostalgic when it was published in 1979. Other writers dip the ethnographic toe into ageing b-boying communities, post-ravers and queer communities, but it is only when the ghosts of the Birmingham Centre have been tamed and exorcised that the book becomes interesting. Very interesting. While attention to digitisation and disintermediation is lacking, when the focus moves from gathering rich interview data to shaping that data in the service of new theories the book offers a great deal to scholars in the field.

Ageing and Youth Cultures gets its mojo working in Joanna Davis's fine chapter 'Punk, Ageing and the Expectations of Adult Life':

Because of its focus on youth, the concept of subculture is not as helpful in making sense of the complex and subtle process of identity negotiation participants experience as they grow into adulthood. The concept of the scene, however, is more useful because it denotes the openness that adult cultural experiences would demand. (106)

$\cdots$

Incorporating ideologies of punk into one's life opens up a possible way to go about 'adulthood', and suggests the ways in which values and ideologies linked to traditional youth 'subcultural' participation can be translated or transported into one's life. Taking on punk as a lifestyle requires confronting the so-called inevitabilities of adulthood. (108)

Cleverly, Davis realises that part of the redefinition of punk-a post-youth culture in so many ways-requires a reconceptualisation of adulthood and its 'other'. Managing punk parenthood activates some of this complexity, which is why it makes 
such a rich resource for theorisations of the self through myriad contexts. This complexity is continued by Samantha Holland's 'Alternative Women Adjusting to Ageing: How to Stay a Freak at Fifty'. While Holland's research began in the McRobbie zone of women's absence from youth subcultural theory, her study quickly became more intricate when she realised women were not 'growing out' of being alternative. Obviously, 'alternative to what' remains the question. Holland interviewed the same people after a gap of ten years, logging both the impact of the increasing sexualisation of popular culture and the proliferation of digitisation. The ambivalence expressed by her interviewees around 'toning down' provides a foundation for further study.

The standout chapter from both books is Paul Hodkinson's 'The Collective Ageing of a Goth Festival'. Goths were and are a distinct subculture. What makes this study so fascinating is that the entire subculture has collectively aged. As they have become older, their community has intensified through an event: the Whitby Gothic Weekend. Starting in 1994, the festival has continued as the participants have gained jobs, partners and children. They may be 'partying softer', (147) but the community is recalibrating. Intriguingly, so are the retailers at the festival. The clothes have been adapted to include goth wedding regalia, and the sizes and shapes have become larger to target the widening goth consumer.

The final two chapters of Ageing and Youth Culture continue in this careful and subtle vein. Kristen Schilt and Danielle Giffort track the passage from Riot Grrrls to Riot Women. They study rock camps and how generational change is managed through the sharing of history and a DIY ideology. The writers observe that Riot Women 'did not "grow out" of punk rock feminism, but rather found a new avenue for expressing their ideologies'. (158) The final stunning study is Nicola Smith's 'Parenthood and the Transfer of Capital in the Northern Soul Scene'. Focusing on British Northern Soul and the dancing and drug use that accompanied it, Smith tracks the different stages of soul participation with particular attention to 'microfamilial inheritance'. (159) In a timely investigation of generationally shared music tastes, Smith shows that Northern Soul is embodied and perpetuated in the home rather than the dance floor.

Youth is a crossroads culture, occupying spaces and colonising times. Yet, as these studies show, youth is far more than a description of an age group, a stage or a 
rite of passage. To rewrite E.P. Thompson's statement on the working class, youth was present at its own making. Youth culture is not the amorphous result of illdefined social changes but made within an economic system that required niche markets to actively increase the rate and role of consumption. Consumption is a trace of how communities, collectives and groups produce meaning. During the 1950s and 1960s, youth became a metaphor for social change with the consumer boom and the emergence of an identifiable teenage market assisting the formation of this 'revolution'. It was the 1980s that offered a break in this narrative. As a result of structural unemployment, youth were no longer required as a market. They were therefore unmade. While the mods, rockers and punks were over-invested with radical or revolutionary potential, the post-youth of the $1980 \mathrm{~s}$, through their stylelifeing, were framed as a travesty or betrayal of the 'authentic' political moments of 1968 and 1976. They were 'Thatcher's children'. If political change is found only in a masculinist, heterosexual, productive public domain, then style-lifeing is demeaned as an ephemeral, trivial waste. If-as shown through these two edited collectionsstyle becomes a force for revelation, not revolution, then a new locomotive of history is tracked.

After the global financial crisis, underemployment, and hyper-consumption, collectivity and community can still be summoned in our present. But it coalesces through shared popular culture and literacy, rather than consciousness of class and injustice. Homology, as a sociological concept to understand the alignment and replication of social formations, is no longer appropriate to the political realities of a post-Thatcher and Reagan world. That is why baby boomers always appear more radical than their children. It is significant that the Birmingham Centre had produced its most influential research by 1980 . The $1980 \mathrm{~s}$ signalled the popularisation of newness: new theories, styles and cultures. Markers on the passage to adulthood transformed during these years. As Pamela Abbott and Claire Wallace asked in 1991, 'what is the point of socialising someone for manual work, when industry is in decline: or socialising young women into the role of mothers when they may not have children?'1 Without steady employment, a mortgage and family responsibilities, post-youth never made it into adulthood as defined by the standards of preceding decades. 
This review began with an epigraph from the Pet Shop Boys' feature film, It Couldn't Happen Here. A blind Catholic priest, who is also a murderer, steps into Chris Lowe's car and says, 'I smell youth, vintage youth'. Later used to introduce their music video 'Always on My Mind', this phrase cues a different version of postyouth culture. The Pet Shop Boys, the duo that 'played a different game', remain suave guides to the vestiges of vintage youth. Since their formation in 1981, the Pet Shop Boys have settled into an important role: the undertakers of popular music. They gather the dark, damaged and decaying. Neil Tennant's mournful tones, confirming that there will not be a happy ending to love or lust, are counterpoised with the hopeful swirling synthesisers of disco. Reviewing their 2006 album Fundamental on Playlouder, the digital music provider that has been in virtual partnership with Glastonbury since 2000, Luke Turner considered that the Pet Shop Boys have 'rightly realised that making an album chock-full of screaming camp bangers would merely make them look like a pair of decaying, bleach-blond queens spilling out of their sleeveless vests in some forsaken provincial nightspot'. ${ }^{2}$ Rather, the evenness of Tennant's tone is lightly tempered with an ice-cold slither of rage. There is none of Coldplay's blandness or Madonna's leotards. Right now, we do not need legwarmers. We require a bright, sharp spotlight hitting the paradoxes of this paranoid time. Defiant rather than boring or compliant, it is the Pet Shop Boys who might be able to fuse ageing and popular culture with political change.

Tara Brabazon is Professor of Education and Head of the School of Teacher Education at Charles Sturt University.

\footnotetext{
-Notes

1 Pamela Abbott and Claire Wallace, Gender, Power and Sexuality, Macmillan, Houndsmill, 1991, p. 10.

2 L. Turner, 'Review of Fundamental', Playlouder, 23 May 2006,

<http://www.playlouder.com/review/+fundamental/>.
} 